\title{
PENERAPAN MODEL PROBLEM BASED LEARNING UNTUK MENINGKATKAN KEMAMPUAN BERFIKIR KRITIS MAHASISWA
}

\author{
Yohana Wuri Satwika \\ Hermien Laksmiwati \\ Riza Noviana Khoirunnisa \\ Universitas Negeri Surabaya \\ E-mail: yohanasatwika@unesa.ac.id
}

\begin{abstract}
Abstrak
Tujuan penelitian ini ialah untuk mendeskripsikan penerapan model Problem Based Learning dalam meningkatkan kemampuan berpikir kritis mahasiswa pada mata kuliah Psikologi Sosial di Jurusan Psikologi Fakultas Ilmu Pendidikan UNESA. Problem Based Learning digunakan untuk merangsang berpikir tingkat tinggi dalam situasi yang berorientasi masalah, termasuk di dalamnya kemampuan berfikir kritis. Melalui penerapan Problem Based Learning ini, mahasisiswa diharapkan dapat menggali dan menemukan sendiri pemecahan masalah yang dibahas dalam proses belajar mengajar didalam kelas. Metode yang digunakan adalah Penelitian Tindakan Kelas (PTK). Sebelum dilakukan penelitian hanya ada 66,6\% mahasiswa dalam kategori "cukup kritis" sedangkan 33,30\% lainnya ada dalam kategori "tidak kritis". Setelah dilakukan tindakan dalam siklus I dan siklus II ditemukan bahwa mahasiswa yang termasuk dalam kategori "sangat kritis" dari yang semula tidak ada meningkat menjadi 29\% sementara itu, untuk kategori "kritis" dari yang semula tidak ada meningkat menjadi 58\% mahasiswa. Dengan demikian, dapat disimpulkan bahwa model pembelajaran berbasis masalah mampu meningkatkan kemampuan berpikir kritis mahasiswa dalam mata kuliah Psikologi Sosial jurusan Psikologi Fakultas Ilmu Pendidikan UNESA.
\end{abstract}

Kata Kunci: Problem Based Learning, berpikir kritis

\begin{abstract}
The purpose of this study was to describe the application of the Problem Based Learning model in improving students' critical thinking skills in the Social Psychology course at the Psychology Department of the Faculty of Education at UNESA. Problem Based Learning is used to stimulate high-level thinking in problem-oriented situations, including the ability to think critically. Through the application of Problem Based Learning, students are expected to explore and find their own problem solving discussed in the teaching and learning process in the classroom. The method used is Classroom Action Research. Before to the study there were only $66.6 \%$ of students in the "quite critical" category while the other $33.30 \%$ were in the "uncritical" category. After the study with cycle I and cycle II found that students included in the category of "very critical" from none is increase to $29 \%$ of student while for the "critical" category from none is increase to $58 \%$ of students. Thus, it can be concluded that the problem-based learning model is able to improve students' critical thinking skills in the Social Psychology course at the Psychology Department of the Faculty of Education at UNESA.
\end{abstract}

Keyword: Problem Based Learning, critical thinking

\section{PENDAHULUAN}

Pendidikan usia yang diharapkan memampukan peserta didik untuk menjadi manusia yang cerdas, berilmu dan berpengetahuan serta terdidik (Hamzah, 2007). Proses pendidikan adalah proses yang sangat kompleks karena dipengaruhi oleh keterikatan antara pengajar, pembelajar dan media pemberlajaran. Ketiga hal tersebut saling mempengaruhi dalam proses pembelajaran dan menentukan keberhasilan proses pembelajaran itu sendiri.

Seiring dengan majunya bidang pendidikan, salah satu bidang ilmu yang juga berkembang dengan cukup pesat saat ini adalah psikologi. Ilmu psikologi dengan berbagai macam cabang dan ilmu terapannya telah berkembang dan telah banyak memberi manfaat bagi kehidupan manusia. Psikologi sosial adalah salah satu cabang ilmu psikologi yang dipelajari secara luas karena 
posisinya yang cukup penting dalam psikologi modern (Baron \& Byrne, 2005)

Pada Jurusan Psikologi di Fakultas Ilmu Pendidikan Universitas Negeri Surabaya, mata kuliah Psikologi Sosial dipelajari sebagai salah satu mata kuliah dasar yang diwajibkan untuk diambil oleh mahasiswa yang sedang menempuh perkuliahan. Mata kuliah Psikologi Sosial ini biasanya akan diambil oleh mahasiswa pada semester kedua atau ketiga masa perkuliahan.

Berdasarkan hasil obervasi awal yang dilakukan peneliti selama proses perkuliahan Psikologi Sosial, khususnya Psikologi Sosial, mahasiswa yang mengikuti perkuliahan cenderung terlihat pasif. Hal ini dapat dilihat dari kurangnya proses tanya jawab yang terjadi dikelas, sehingga kelas terasa seperti "tidak hidup". Ketika proses penyampaian materi perkuliahan oleh dosen, maupun ketika ruang tanya jawab dibuka, hanya sedikit mahasiswa saja yang bertanya. Hal yang sama juga terjadi pada saat dosen mengajukan pertanyaan, hanya sebagian kecil mahasiswa saja yang memberikan pendapatnya dalam menjawab pertanyaan tersebut. Permasalahan yang sama juga terlihat muncul pada saat berlangsung mata kuliah dengan sistem presentasi. Ketika presentasi selesai dilakukan, biasanya diberikan waktu untuk bertanya jawab mengenai permasalahan yang dibahas dalam materi presentasi. Pada saat sesi pertanyaan dibuka, biasanya hanya beberapa mahasiswa saja yang mau bertanya, dari sekitar satu kelas mahasiswa, hanya kurang lebih 3 atau 4 mahasiswa saja yang terlihat mengajukan pertanyaan kepada kelompok yang sedang melakukan presentasi.

Salah satu tugas dari pengajar adalah mendorong peserta didiknya terlibat aktif dalam keseluruhan proses pembelajaran. Proses tersebut meliputi diskusi, berpikir secara kritis, bertanya, dan menjawab pertanyaan termasuk menjelaskan jawaban yang diberikan, serta mengajukan alasan untuk jawaban tersebut. Keterampilan berpikir kritis tidak begitu saja dimiliki oleh peserta didik sehingga sangat perlu untuk dilatih. Sementara itu melihat kondisi yang terjadi di lapangan diketahui belum seluruhnya peserta didik dapat berpikir kritis.

Berdasarkan hasil observasi awal yang dilakukan oleh peneliti juga dapat dilihat bahwa kemampuan mahasiswa mengungkapkan ide dan memberikan pendapat juga rendah. Hal ini terbukti ketika dalam proses perkuliahan, pengajar mempersilahkan mahasiswa untuk memberikan ide dan pendapatnya mengenai sebuah kasus atau fenomena yang disajikan sebagai bahan diskusi dan analisa. Hanya sedikit mahasiswa saja yang bersedia memberikan pendapatnya, kecuali apabila ditunjuk secara acak atau diminta mewakili sebuah kelompok.

Berpikir kritis atau biasa disebut berpikir tingkat tinggi merupakan keterampilan berpikir mengolah segala informasi, observasi dan permasalahan yang didapat, dengan membuat keputusan apa yang harus dilakukan disertai dengan logika. Hal ini membuat berpikir menjadi hal yang dirasa penting terutama dalam proses pembelajaran. Seseorang dalam berpikir pada dasarnya dilandasi dengan rasa ingin tahu, benar atau salahnya proses berpikir. Jaya, Swasono, Baswir, and Prijambada (2015) mengungkapkan bahwa berpikir kritis merupakan bagian dari keterampilan atau kemampuan berpikir tingkat tinggi.

Berpikir kritis penting diterapkan, bukan hanya menghafal teori saja yang mudah dilupakan akan tetapi mampu menganalisis dan memahami maknanya serta memperoleh keterampilan yang berguna bagi kehidupannya dilingkungan masyarakat. Menurut Tinio (dalam Wahyuni, 2011), salah satu ketrampilan yang dibutuhkan untuk menghadapi tantangan di masa yang akan datang adalah keterampilan berpikir kritis (critical thingking) atau keterampilan berpikir tingkat tinggi (higher order thinking). Pentingnya pengembangan kemampuan berpikir kritis ini seharusnya dilakukan sejak pendidikan di tahap awal hingga pendidikan tingkat tinggi sekalipun masih diperlukan. Alasan inilah yang membuat perlu adanya pembelajaran yang lebih banyak melibatkan proses pembelajaran berpikir.

Fenomena kurangnya kemampuan berfikir kritis pada mahasiswa seperti yang diungkapkan oleh peneliti diatas juga terlihat dialami oleh banyak pengajar lain di berbagai universitas dan perguruan tinggi, baik di Indonesia, maupun di negara-negara lain. Masalah pembelajaran yang diuraikan diatas dapat dilatarbelakangi oleh metode pembelajaran yang selama ini masih menggunakan metode konvensional. Metode mengajar secara konvensional dilakukan dengan cara memberi ceramah. Dengan metode tersebut, mahasiswa lebih sering hanya mendengarkan saja dan mencatat apa yang dijelaskan oleh pengajar, sebagai akibatnya mahasiswa kemungkinan tidak memiliki konsep materi yang utuh mengenai mata kuliah yang sedang dibahas (Dwijananti \& Yulianti, 2010).

Pemilihan model pembelajaran yang tepat dapat membantu memperjelas materi akan yang disampaikan. Beberapa penelitian mengungkapkan bahwa salah satu metode yang dapat digunakan untuk meningkatkan kemampuan berfikir kritis pada mahasiswa adalah dengan metode Problem Based Learning (PBL). Salah satunya adalah penelitian dengan judul Measuring the Effects of Problem-Based Learning on the Development of Postformal Thinking Skills and Engagement of FirstYear Learning Community Students yang dilakukan oleh Wynn Sr, Mosholder, and Larsen (2014). Dalam penelitian ini dibahas mengenai penelitian dengan metode PBL sebagai pendekatan yang berguna menstimulasi refleksi metakognitif dalam diskusi dan integrasi ke dalam komunitas belajar. Penelitian ini menggunakan kerangka kerja Neo-Piagetian untuk membangun pendekatan refleksi metakognitif yang juga mengidentifikasi target target yang mencerminkan kemampuan berfikir tingkat tinggi dan kemampuan penyelesaian permasalahan kompleks pada orang dewasa.

Model PBL dirasa tepat untuk mengembangkan kemampuan berpikir kritis peserta didik dalam menemukan dan memecahkan masalah. Model PBL ini mengembangkan bagaimana masalah yang dibahas berkaitan dengan dunia nyata dala kehidupan sehari- hari. Dengan penggunaan model pembelajaran ini peserta 
didik akan melati dan mengasah ketrampilan berpikir kritis mereka untuk memperoleh pengetahuan dari materi pelajaran (Daryanto \& Tarno, 2015). Oleh sebab itu, model PBL dapat menjadi salah satu solusi untuk mendorong peserta didik berpikir dan bekerja ketimbang hanya sekedar menghafal dan bercerita (Trianto, 2010).

$$
\text { Menurut Snyder and Wiles (2015) }
$$

kemampuan berfikir kritis dapat dikembangkan dengan metode pengajaran yang berpusat pada siswa / peserta didik. PBL pada awalnya adalah pendekatan pedagogis yang awalnya dikembangkan disekolah medis. Masalah dalam pendekatan PBL menjadi stimulus bagi peserta didik dalam kegiatan belajar. Sementara belajar itu sendiri ditujukan untuk mencari alternatif solusi dari masalah sesuai dengan konteks pengathuan yang ada (Orozco \& Yangco, 2016).

Seng (2009) menuliskan bahwa PBL meningkatkan kemampuan berfikir tingkat tinggi, pengetahuan konstruksi, pembelajaran konstruktif dan kemandirian dalam belajar. Hal inilah yang sangat diperlukan dalam proses pembelajaran dikelas khususnya dengan peserta didik mahasiswa yang dituntut memiliki kemampuan-kemampuan tersebut terkait dengan kompetensi profesional mereka setelah lulus dari bangku perkuliahan. Lebih jauh dalam Seng juga menjelaskan pula bahwa PBL juga membantu pengajar dan peserta didik mengembangkan dan mencapai tujuan pendidikan yakni penguasaan konten materi, pemecahan masalah, kerjasama tim dan menjadikan siswa pembelajar seumur hidup.

Dari uraian diatas dapat dilihat bahawa salah satu metode yang dapat dilakukan untuk mengatasi masalah rendahnya kemampuan berfikir kritis pada mahasiswa adalah ini adalah dengan model PBL. Oleh karena itu penulis berencana menggunakan model ini dalam penelitian tidakan kelas yang akan dilakukan.

Berdasarkan latar belakang yang telah diuraiakn diatas maka dapat disusun rumusan masalah dalam penelitian ini adalah sebagai berikut : 1) Bagaimana penerapan model pembelajaran Problem Based Learning dalam mata kuliah Psikologi Sosial 2) Bagaimana peningkatan kemampaun berfikir kritis mahasiswa setelah penerapan model pembelajaran Problem Based Learning dalam mata kuliah Psikologi Sosial

\section{METODE PENELITIAN}

Pendekatan penelitian yang digunakan peneliti adalah Penelitian Tindakan Kelas (PTK). Penelitian tindakan kelas adalah kajian yang sistematik dari upaya perbaikan pelaksanaan praktek pendidikan oleh pengajar dalam melakukan tindakan-tindakan dalam pembelajaran, berdasarkan refleksi mereka mengenai hasil dari tindakan-tindakan tersebut.

Menurut Suharsimi (2006) penelitian tindakan kelas adalah pengamatan yang dilakukan terhadap proses belajar mengajar berupa sebuah tindakan, yang sengaja dimunculkan yang terjadi pada sebuah kelas secara bersamaan. Prosedur penelitian terdiri dari 4 tahap, yakni tahap yaitu perencanaan (planning), tindakan (action), pengamatan (observation), dan refleksi (reflective). Pelaksanaan pengumpulan data dalam penelitian ini dilakukan dalam dua kali putaran dan tiap putaran pada penelitian ini mengikuti alur rancangan penelitian tindakan. Garis besar penelitian disusun sesuai rancangan penelitian tindakan kelas (PTK) dalam bentuk bagan seperti yang digambarkan sebagai berikut:

\section{Rencana Tindakan}

Pada tahapan ini dosen sebagai pengajar pada tahap ini menyiapkan RPS dan bahan ajar berupa modul dan handout, lembar kerja mahasiswa, lembar observasi pelaksanaan PBL

\section{Implementasi Tindakan}

Pelaksanaan tindakan pada siklus pertama dilakukan dalam satu kali pertemuan. Tahap tindakan dilakukan oleh dosen dalam hal ini adalah peneliti dengan menggunakan model PBL. Proses pembelajaran dilakukan sesuai jadwal mata kuliah Psikologi Sosial. Pembentukan kelompok dilakukan sebelum minggu ke tiga atau pertemuan ke tiga, masing-masing kelompok terdiri dari 3-4 mahasiswa. Materi yang akan diberikan adalah berupa studi kasus tentang materi yang sedang dibahas, misalnya mengenai "persuasi", maka kasus yang diberikan adalah berupa pengaruh media iklan dan persuasi personal dalam kehidupan sehari-hari. Adapun tindakan yang dilakukan dalam siklus 1 adalah:

a. Pendahuluan $( \pm 15$ Menit $)$

- Membimbing berdoa sesuai dengan agama masing-masing

- Memberikan kesempatan kepada mahasiswa untuk menggali informasi

- Mengorientasikan masalah yang akan dicari pemecahannya secara berkelompok

- Mengkomunikasikan tujuan pembelajaran produk, proses, psikomotor, perilaku berkarakter dan keterampilan sosial

b. Kegiatan inti ( \pm 70 Menit $)$

- Mengorganisasi mahasiswa untuk belajar dengan memberikan LKM

- Mengungkapkan hal-hal yang tidak dimengerti dalam LKM serta membantu temannya yang kesulitan

- Memecahkan masalah yang telah dipilih

- Melakukan penyelidikan setahap demi setahap diawali dengan perumusan masalah Merumuskan hipotesis atas rumusan masalah yang telah dibuat

- Menguji hipotesis yang sudah dirumuskan

- Mengembangkan dan menyajikan hasil diskusi yang telah dibuat

- Menyajikan hasil diskusi dengan penuh tanggung jawab

c. Penutup ( $(+15$ Menit $)$

- Bersama-sama menganalisis dan evaluasi pemecahan masalah

- Memberikan apresiasi dan feed back atas hasil kerja mahasiswa

\section{Pengamatan}

Pengamatan dilakukan selama proses pembelajaran dengan menggunakan lembar 
observasi yang telah disiapkan dan mencatat kejadian-kejadian yang tidak terdapat dalam lembar observasi dengan membuat lembar catatan lapangan. Hal-hal yang diamati selama proses pembelajaran adalah kegiatan pembelajaran dan aktivitas pengajar maupun mahasiswa selama pelaksanaan pembelajaran.

\section{Refleksi}

Pada tahap ini pengajar melakukan evaluasi dari pelaksanaan tindakan pada siklus I yang digunakan sebagai bahan pertimbangan perencanaan pembelajaran siklus berikutnya. Jika hasil yang diharapkan belum tercapai maka dilakukan perbaikan yang dilaksanakan pada siklus kedua dan seterusnya.

\section{HASIL PENELITIAN DAN PEMBAHASAN}

Berdasarkan pengamatan awal dan diskusi dengan tim dosen pengampu mata kuliah Psikologi Sosial diperoleh gambaran mengenai kondisi pembelajaran di kelas pada mahasiswa angkatan 2016. Materi dalam mata kuliah Psikologi Sosial disampaikan oleh dosen dengan menggunakan metode pembelajaran aktif dan memanfaatkan media yang tersedia di kelas. Penerapan metode ini belum optimal untuk meningkatkan kemampuan berfikir kritis mahasiswa karena pada umumnya para dosen masih menggunakan metode ceramah secara satu arah.

Dari observasi awal terlihat bahwa mahasiswa masih kurang mampu untuk memberikan contoh kasus di dalam masyarakat, mahasiswa juga kurang bergairah dalam perkuliahan, malu bertanya dan mengungkapkan pendapat masing - masing individu dan kurangnya minat mahasiswa dalam mengerjakan tugas yang diberikan dosen. Apabila diadakan diskusi, mahasiswa juga kurang memahami apa yang disampaikan oleh kelompok lain, mahasiswa cenderung terpaku pada satu bahasan yang ada di kelompoknya sendiri dan kelompok lain tidak memahami apa yang disampaikan bahkan cenderung terlihat gaduh sendiri. Kondisi ini menunjukkan siswa belum mengembangkan aktivitas berpikir, khususnya berpikir kritis. Oleh karena itu, siswa kurang memahami materi perkuliahan yang disampaikan guru dan hasil pembelajaran kurang maksimal.

Berdasarkan kondisi dan data awal tersebut diperlukan adanya tindakan untuk membantu mahasiswa dalam memahami materi untuk meningkatkan keterampilan berpikir kritis mahasiswa. Langkah yang diambil dalam penelitian ini yaitu dengan menerapkan model PBL yang diharapkan dapat meningkatkan peran aktif siswa dalam pembelajaran sehingga dapat meningkatkan keterampilan berpikir kritis siswa.

Berikut ini adalah hasil observasi awal mengenai kemampuan berfikir kritis mahasiswa pada perkuliahan Psikologi Sosial.

Tabel 1. Klasifikasi Kemampuan Berpikir Kritis Awal

\begin{tabular}{cccc}
\hline Skor & Klasifikasi & $\begin{array}{c}\text { Jumlah } \\
\text { Mahasiswa }\end{array}$ & Prosentase \\
\hline $81-$ & Sangat & 0 & $0 \%$ \\
$100 \%$ & Kritis & mahasiswa & $0 \%$ \\
\hline
\end{tabular}

\begin{tabular}{|c|c|c|c|}
\hline Skor & Klasifikasi & $\begin{array}{c}\text { Jumlah } \\
\text { Mahasiswa }\end{array}$ & Prosentase \\
\hline $\begin{array}{c}63- \\
80 \%\end{array}$ & Kritis & 0 mahasiswa & $0 \%$ \\
\hline $\begin{array}{l}43- \\
62 \%\end{array}$ & $\begin{array}{l}\text { Cukup } \\
\text { Kritis }\end{array}$ & $\begin{array}{c}16 \\
\text { mahasiswa }\end{array}$ & $66,6 \%$ \\
\hline $\begin{array}{l}25- \\
42 \%\end{array}$ & $\begin{array}{c}\text { Kurang } \\
\text { Kritis }\end{array}$ & $\begin{array}{c}8 \\
\text { mahasiswa }\end{array}$ & $33,30 \%$ \\
\hline
\end{tabular}

\section{Hasil Penelitian Siklus I}

Adapun kegiatan yang dilakukan selama proses pembelajaran pada siklus I meliputi tahap perencanaan, tindakan, pengamatan dan refleksi diuraikan sebagai berikut :

\section{a. Perencanaan (Planning)}

Pada siklus I peneliti menyampaikan materi mengenai konsep "Agresi". Dalam tahapan ini peneliti menyampaikan tujuan pembelajaran yang hendak dicapai yaitu menerapkan model pembelajaran berbasis masalah untuk meningkatkan berpikir kritis. Materi ajar yang digunakan bertujuan untuk memberikan pengetahuan dan wawasan pada mahasiswa tentang materi tersebut

b. Pelaksanaan (Acting)

Pada tahap pelaksanaan pada fase penelitian tindakan kelas ini peneliti memulai materi dengan memberikan apersepsi sebagai upaya untuk memberikan rangsangan kepada mahasiswa agar lebih siap dalam mengikuti perkuliahan. Peneliti menyampaikan tujuan pembelajaran yang ingin dicapai. Selanjutnya, peneliti menyampaikan topik mengenai konsep dasar agresi selama 15 menit. Penjelasan peneliti ini diharapkan dapat merangsang kepekaan siswa terhadap masalah yang menjadi materi perkuliahan. Pada kegiatan ini, peneliti menyampaikan skenario pembelajaran mengenai pelaksanaan model pembelajaran berbasis masalah, yakni dengan diskusi kasus dalam kelompok untuk menggali permasalahan dalam ranah psikologi sosial.

Diskusi kelompok berlangsung selama 45 menit dan setiap kelompok mempresentasikan sub topik permasalahan di depan kelas pada pertemuan berikutnya. Setiap perwakilan kelompok maju ke depan kelas secara acak. Setiap perwakilan kelompok mempresentasikan hasil diskusinya, peneliti mulai membimbing mahasiswa dalam mengemukakan ide atau pendapat, dan pertanyaan. Selama diskusi diharapkan mahasiswa mengembangkan keterampilan berpikir kritis.

\section{c. Pengamatan (Observing)}

Selama siklus I berlangsung peneliti mengamati keterampilan berpikir kritis terhadap 6 kelompok. Berdasarkan hasil diskusi setiap kelompok yang ditulis di lembar kerja diskusi dan selama pelaksanaan pembelajaran dapat disimpulkan bahwa keterampilan berpikir kritis siswa termasuk dalam kategori cukup kritis dengan persentase 54,15\% dan kategori kritis dengan persentase 45,8\%. Berikut ini adalah hasil observasi pada siklus I mengenai kemampuan berfikir kritis mahasiswa pada perkuliahan Psikologi Sosial. 
Tabel 2. Klasifikasi Kemampuan Berpikir Kritis Siklus I

\begin{tabular}{cccc}
\hline Skor & Klasifikasi & $\begin{array}{c}\text { Jumlah } \\
\text { Mahasiswa }\end{array}$ & Prosentase \\
\hline $81-$ & Sangat Kritis & 0 mahasiswa & $0 \%$ \\
$100 \%$ & Kritis & 11 mahasiswa & $45,85 \%$ \\
$63-80 \%$ & Cukup Kritis & 13 mahasiswa & $54,15 \%$ \\
$43-62 \%$ & Kurang Kritis & 0 mahasiswa & $0 \%$ \\
$25-42 \%$ & Kura \\
\hline
\end{tabular}

\section{d. Refleksi (Reflecting)}

Berdasarkan indikator yang telah ditentukan, keterampilan berfikir kritis mahasiswa selama peperkuliahan perlu ditingkatkan karena termasuk kategori "cukup kritis" dengan persentase 54,15\% dan kategori "kritis" 45,8 \%. Oleh karena itu, peneliti merencanakan tindakan berikut pada siklus II karena pada siklus I belum mencapai target yang ditentukan sesuai dengan indikator tersedia.

\section{Hasil Penelitian Siklus II}

\section{a. Perencanaan (Planning)}

Pada siklus II peneliti menyampaikan materi mengenai konsep "Prososial". Dalam tahapan ini peneliti menyampaikan tujuan pembelajaran yang hendak dicapai yaitu menerapkan model pembelajaran berbasis masalah untuk meningkatkan berpikir kritis. Materi ajar yang digunakan bertujuan untuk memberikan pengetahuan dan wawasan pada mahasiswa tentang materi tersebut

\section{b. Pelaksanaan (Acting)}

Pada tahap pelaksanaan pada fase penelitian tindakan kelas ini peneliti memulai materi dengan memberikan apersepsi sebagai upaya untuk memberikan rangsangan kepada mahasiswa agar lebih siap dalam mengikuti perkuliahan. Peneliti menyampaikan tujuan pembelajaran yang ingin dicapai. Selanjutnya, peneliti menyampaikan topik mengenai konsep dasar agresi selama 15 menit. Penjelasan peneliti ini diharapkan dapat merangsang kepekaan siswa terhadap masalah yang menjadi materi perkuliahan. Pada kegiatan ini, peneliti menyampaikan skenario pembelajaran mengenai pelaksanaan model pembelajaran berbasis masalah, yakni dengan diskusi kasus dalam kelompok untuk menggali permasalahan dalam ranah psikologi sosial.

Diskusi kelompok berlangsung selama 45 menit dan setiap kelompok mempresentasikan sub topik permasalahan di depan kelas pada pertemuan berikutnya. Setiap perwakilan kelompok maju ke depan kelas secara acak. Setiap perwakilan kelompok mempresentasikan hasil diskusinya, peneliti mulai membimbing mahasiswa dalam mengemukakan ide atau pendapat, dan pertanyaan. Selama diskusi diharapkan mahasiswa mengembangkan keterampilan berpikir kritis.

\section{c. Pengamatan (Observing)}

Selama siklus II berlangsung peneliti mengamati keterampilan berpikir kritis terhadap 6 kelompok. Berdasarkan hasil diskusi setiap kelompok yang ditulis di lembar kerja diskusi dan selama pelaksanaan pembelajaran dapat disimpulkan bahwa keterampilan berpikir kritis mahasiswa termasuk dalam kategori "cukup kritis" dengan persentase 12,5\%, kategori "kritis" dengan persentase 58,3\% dan kategori "sangat kritis" dengan persentase $29,16 \%$. Sementara untuk kategori "kurang kritis" sudah sama sekali tidak ada. Berikut ini adalah hasil observasi pada siklus II mengenai kemampuan berfikir kritis mahasiswa pada perkuliahan Psikologi Sosial.

Tabel 3. Klasifikasi Kemampuan Berpikir Kritis Siklus II

\begin{tabular}{cccc}
\hline Skor & Klasifikasi & $\begin{array}{c}\text { Jumlah } \\
\text { Mahasiswa }\end{array}$ & Prosentase \\
\hline $81-100 \%$ & Sangat Kritis & 7 mahasiswa & $29,16 \%$ \\
$63-80 \%$ & Kritis & 14 mahasiswa & $58,3 \%$ \\
$43-62 \%$ & Cukup Kritis & 3 mahasiswa & $12,50 \%$ \\
$25-42 \%$ & Kurang & 0 mahasiswa & $0 \%$ \\
\hline
\end{tabular}

\section{d. Refleksi (Reflecting)}

Berdasarkan hasil penelitian pada siklus II diperoleh analisis data - data yang nyata bahwa setelah adanya pembelajaran menggunakan model PBL terlihat adanya suatu peningkatan kemampuan berfikir kirtis.

Berdasarkan hasil observasi PBL pada tahapan awal diperoleh data bahwa hanya ada $66,6 \%$ persentase mahasiswa yang termasuk dalam kategori "cukup kritis" dan tidak ada satupun mahasiswa dalam kategori "kritis" dan "sangat kritis". Pada tahapan tersebut peneliti belum memberdayakan pertanyaan provokatif untuk memancing kemampuan berpikir kritis mahasiswa selain itu dosen masih sering membantu mahasiswa dalam pengerjaan tugas sehingga membuat mahasiswa tidak mandiri. Berdasarkan refleksi tindakan pembelajaran bersama peneliti dan observer, peneliti dapat meningkatkan persentase pencapaian pembelajaran siklus berikutnya, peneliti sudah melakukan semua indikator PBL sehingga terdapat peningkatan persentase mahasiswa dalam kategori "sangat kritis" dari yang semula tidak ada menjadi $29 \%$, kategori "kritis" dari yang semula tidak ada menjadi $58 \%$. Hal ini sesuai dengan tujuan PBL adalah membantu mengembangkan keterampilan memecahkan masalah dan kemampuan berpikir kritis, keterampilan intelektual, belajar tentang berbagai peran orang dewasa melalui pelibatan mereka dalam pengalaman nyata atau simulasi dan menjadi pebelajar yang otonom dan mandiri (Nurhadi \& Senduk, 2004).

Peningkatan ini disebabkan karena sebelum memasuki siklus II mahasiswa sudah memiliki pengalaman dan kemampuan awal yang diperoleh pada siklus I. Berdasarkan hasil penelitian pada siklus I dan II dapat dilihat bahwa dengan model PBM dalam proses pembelajaran di kelas mahasiswa menunjukkan peningkatan dalam kemampuan berfikir kritis.

Hasil dalam penelitian ini sejalan dengan penelitian yang dilakukan oleh Marpaung (2005) yang 
juga menhasilkan data bahwa model PBL dapat diterapkan untuk melatih kemampuan berpikir kritis.

Beberapa hal yang dapat mendukung tentang peningkatan kemampuan berfikir kritis pada mahasiswa dengan model PBM dapat dijelaskan sebagai berikut. Pertama, para mahasiswa dalam penelitian ini sedangkan dalam hasa remaja akhir dimana pada saat tersebut adalah periode kritis / transisi untuk perkembangan kemampuan berfikir (kognitif). Hal ini dibahas dalam penelitian Wynn (2010); Wynn Sr et al. (2014) dimana karakteristik perkembangan kognitif mahasiswa cocok bila diberikan model pembelajaran yang merangsang model berfikir dengan permasalahan, kasus, dan diskusi pemecahan masalah seperti yang terdapat dalam model PBL. Kedua, terkait dengan peran dosen dalam pembelajaran model PBL dan suasana kelas. Dalam model PBL ini dosen berperan sebagai fasilitator sehingga mahasiswa berperan aktif dalam poses belajar. Dalam peneletian Wynn $\mathrm{Sr}$ et al. (2014) dijelaskan bahwa suasana belajar dalam model PBL bisa dirasakan lebih hidup dikarenakan dalam proses PBL siswa diharuskan untuk ikut aktif baik dalam berfikir dan mengungkapkan hasil pikirannya sehingga keterlibatan dan kolaborasi mahasiswa juga tinggi. Hal inilah juga yang dapat dicermati dalam penelitian ini bahwa setelah dosen menggunakan model PBL ini respon mahasiswa dan juga suasana perkuliahan menjadi lebih kondusif sehingga mendukung peningkatan kemampuan berfikir kritis juka dilihat dari siklus penelitian khususnya siklus II.

\section{KESIMPULAN DAN SARAN}

Berdasarkan hasil penelitian dan pembahasan, dapat disimpulkan bahwa perkuliahan dengan menggunakan model PBL mampu meningkatkan kemampuan berpikir kritis mahasiswa pada mata kuliah Psikologi Sosial Jurusan Psikologi Fakultas Ilmu Pendidikan Universitas Negeri Surabaya. Hal ini dapat dilihat dari hasil rata - rata prosentase kemampuan berpikir kritis yang diobservasi pada siklus I sampai dengan siklus II yang mengalami peningkatan hingga mencapai indikator keberhasilan.

Berdasarkan hasil penelitian ini dapat dikemukakan saran bahwa perlu kiranya mencoba menggunakan model pembelajaran lainnya seperti problem posing maupun problem solving dan dalam pelaksanaan model PBL guna meningkatkan kemampuan berpikir kritis mahasiswa hendaknya mempertimbangkan kesesuaian materi, karena dibutuhkan waktu yang relative panjang.

\section{DAFTAR PUSTAKA}

Baron, R. A., \& Byrne, D. (2005). Psikologi sosial. Jakarta: Erlangga.

Daryanto, \& Tarno, H. (2015). Pengelolaan Budaya dan Iklim Sekolah: Yogyakarta: Gava Media.

Dwijananti, P., \& Yulianti, D. (2010). Pengembangan kemampuan berpikir kritis mahasiswa melalui pembelajaran problem based instruction pada mata kuliah fisika lingkungan. Jurnal Pendidikan Fisika Indonesia, 6(2).
Jaya, W. K., Swasono, S. E., Baswir, R., \& Prijambada, I. D. (2015). Membangun Kedaulatan Bangsa Berdasarkan Nilai-nilai Pancasila: Pemberdayaan Masyarakat Dalam Kawasan Terluar, Terdepan, dan Tertinggal (3T): Kumpulan makalah call for papers kongres Pancasila VII: Pusat Studi Pancasila UGM.

Marpaung, R. R. T. (2005). Penggunaan Lembar Kegiatan Berbasis Masalah (LKBM) Sebagai Assesmen Alternatif untuk Meningkatkan Kemampuan Berpikir Kritis dan Hasil Belajar Biologi Siswa Kelas VII SMP Laboratorium Universitas Negeri Malang. Tesis tidak diterbitkan. Malang: Program Pascasarjana Universitas Negeri Malang.

Nurhadi, B. Y., \& Senduk, A. G. (2004). Pembelajaran kontekstual dan penerapannya dalam KBK. Malang: Universitas Negeri Malang Pres.

Orozco, J. A., \& Yangco, R. T. (2016). Problem-Based Learning: Effects on Critical and Creative Thinking Skills in Biology. Asian Journal of Biology Education Vol, 9, 3 .

Snyder, J. J., \& Wiles, J. R. (2015). Peer led team learning in introductory biology: Effects on peer leader critical thinking skills. PloS one, 10(1), e0115084.

Suharsimi, A. (2006). Prosedur penelitian suatu pendekatan praktik. Jakarta: Rineka Cipta.

Trianto, M. P. (2010). Model pembelajaran terpadu: Konsep, strategi, dan implementasinya dalam Kurikulum Tingkat Satuan Pendidikan (KTSP). Kuala Lumpur: Kemetrian Pengajaran Malaysia.

Wynn, C. (2010). Promoting cognitive growth through problem-based instruction in a first-year learning community. Journal of Learning Communities Research, 5(2), 5-15.

Wynn Sr, C. T., Mosholder, R. S., \& Larsen, C. A. (2014). Measuring the Effects of Problem-Based Learning on the Development of Postformal Thinking Skills and Engagement of First-Year Learning Community Students. Learning Communities: Research \& Practice, 2(2), 4. 